\title{
SUBSTANTIATION OF CONSTRUCTIVE AND TECHNOLOGICAL PARAMETERS OF DEVICE FOR TWO-STAGE CLEANING OF MILK
}

Ivan Atanov, Ivan Kapustin, Dmitry Gritcay, Elena Kapustina

Stavropol State Agrarian University, Russia

atanovivan@mail.ru, gritcay_kirill@mail.ru, elena79-26reg@mail.ru

\begin{abstract}
In Russia, in 2010 a food security Doctrine was adopted, according to which "food security of the Russian Federation is one of the main directions of ensuring national security of the country". Today the only point of Doctrine, according to which food security is not provided, is milk and dairy products. Our production covers about 65-70 \% needs, $10 \%$ below the target. Very important is also the loss of milk during its production. With an annual milk production of about 30 million tones of milk the production does not exceed $65 \%$ and in private farms $-34 \%$. The relevance of the research problem is due to the lack of domestic equipment for high efficiency cleanup of milk directly on the sites of production. The purpose of this article is to describe the key sources and causes of quality loss of milk. The developments of scientists of the Stavropol Agrarian University for a two-stage cleaning of the milk in terms of dairy farms and complexes are given. Production testing of prototypes of these devices have confirmed their effectiveness. A distinctive feature of the developed filter is the pretreatment of milk from large mechanical inclusions in the collection of them in the sump tank and its fine purification by means of filtration, when passing through the filter element. The filter design is protected by the patent. Production test of the filter showed that it provides the cleaning efficiency of milk from mechanical impurities up to a level sufficient to obtain products of the first group of purity according to the requirements of GOST, The article will be useful to scientists and engineers involved in the development of equipment for primary processing of milk on farms and complexes, as well as dairy plants.
\end{abstract}

Keywords: milk; processing; cleaning; mechanical impurities; filter element.

\section{Introduction}

Milk and dairy products play an important role in the life-support of the country's population. Liquid whole-milk and cultured buttermilk products, cream, cheese, cottage cheese, dairy butter, dried milk (skimmed and whole) are referred to the "milk and dairy products" category (Fig. 1). Dried butterfat, whey, condensed dairy products, milk- protein concentrates, ice cream also belong to this category. The most popular cultured buttermilk products are kefir, curdled milk, acidophilin, yoghurt (including Greek), tan, ayran, kumis, butter whey, fermented baked milk, scour milk, varenets. The world consumption of dairy products including milk, cheese and butter is expected to grow by $36 \%$ in the near future, reaching 710 million tons in milk equivalent in 2024.

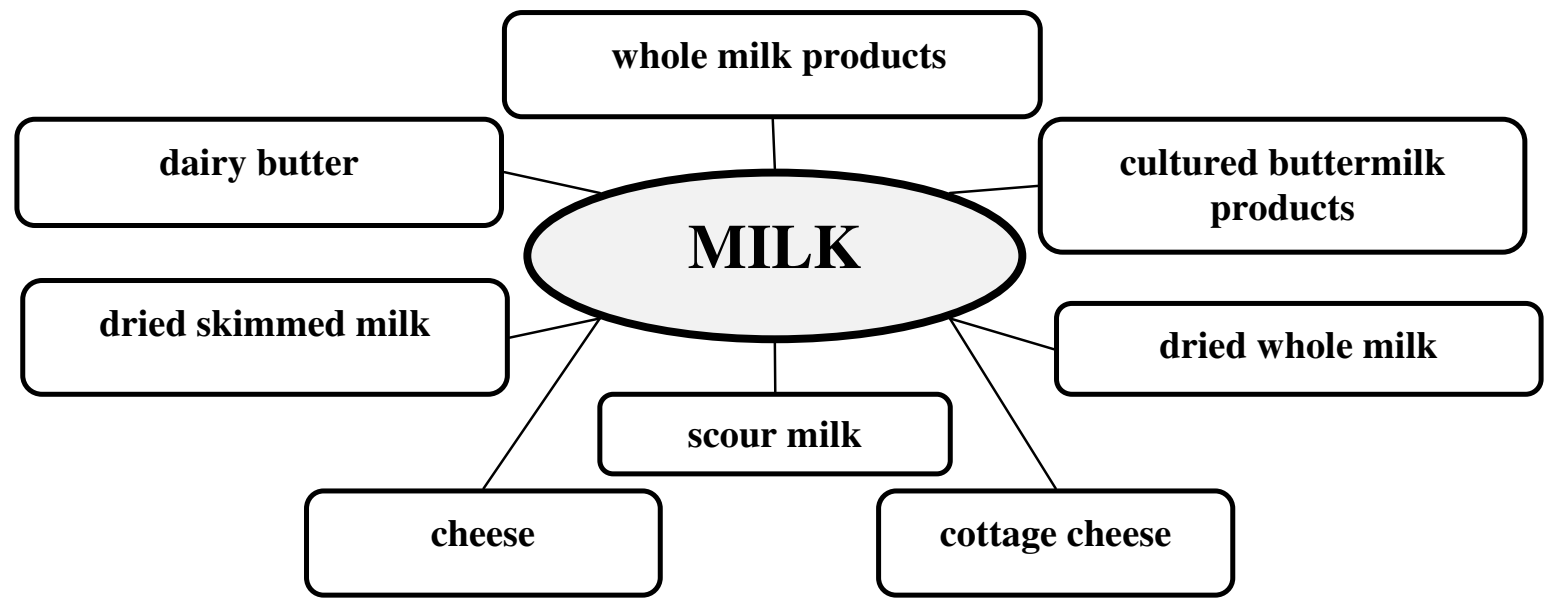

Fig. 1. Dairy foodstuffs

In the Russian Federation, the development of dairy farming was characterized by a steady increase in milk production until 1991. So in 1990, 55.7 million tons of milk or $376 \mathrm{~kg}$ in per capita terms were produced in all categories of farms. It was a maximum level achieved in Russia. However, from 1991 to 2000, there was a sharp decrease both in milk production due to a reduction in cattle heads in the public sector of livestock farming and reducing the productivity [1-3]. 
The implementation of the Russia Food Security Doctrine adopted in 2010 is the main direction of ensuring national security in the country. Today, the only point of the Doctrine, according to which the country food security is not secured, is milk and dairy products. In 2017, milk production in the Russian Federation in all categories of farms was 31.12 million tons, which by $10 \%$ is lower than a target and covers about $65-70 \%$ of the needs (Fig. 2).

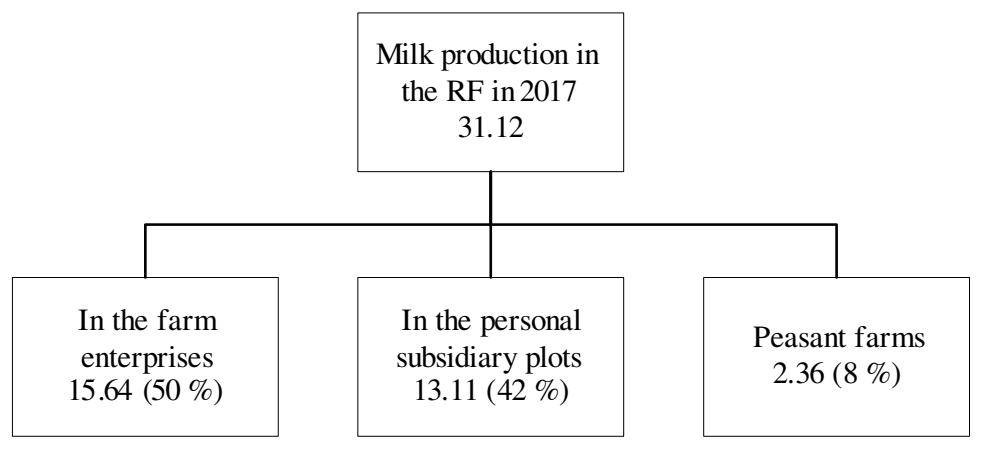

Fig. 2. Milk production in Russian Federation in 2017 according to farm categories, millions tons

According to the available data, annual milk production in the RF should be 50-55 million tons to ensure the satisfaction of the population's demand for milk and dairy products. However, in conformity with the main target indicators of the State Program for Livestock Farming Development by 2020 , the level of milk production should reach 38.2 million tons. To achieve a required level of milk production per capita terms, the annual productivity of the existing dairy cows should not be lower than $6500 \mathrm{~kg}$, being not realistic in the short term. Therefore, the implementation of this problem will be carried out in two directions:

- comprehensive approach to increase the productivity of cows by maximizing the use of their genetic potential;

- increase the heads of high-yield dairy cows.

At present in the Stavropol Territory, the livestock population of dairy cows is 200.3 thousand heads, and the annual milk production covers $76 \%$ of the people's demand of the region. An important feature of dairy cattle breeding in the Stavropol Territory is its small commodity production, characterized by a significant predominance of personal subsidiary plots and farm enterprises, which produce $77.9 \%$ of milk in its total volume. If to compare the Krasnodar Territory, these sectors produce only $37 \%$ of milk and the main milk production is concentrated in agricultural enterprises.

Nevertheless, the Stavropol Territory remains to be a leader among the Russian regions for milk production per capita. According to the regional Ministry of Agriculture, now this figure is $243 \mathrm{~kg}$, whereas it does not exceed $220 \mathrm{~kg}$ on the average in the country (Fig. 3). It should be noted that not all milk produced is suitable for production of dairy products. Only the so-called marketable milk is used for processing, the bulk of which is produced by agricultural enterprises in the Russian Federation. Today in many regions of the country, personal subsidiary plots occupy the leading position in the gross output of milk, being a main reason for its low marketability. If milk marketability produced by the farm enterprises reaches $94 \%$, but in the households it is only $34 \%$ (Fig. 4), which substantially reduces the amount of raw milk actually available to specialists of milk processing. This trend has a stable and mostly negative character, determined by seasonality of milk production with its extremely low qualitative indicators.

In 2017, the production of marketable milk on the farms of all categories in the RF reached 21.2 million tons. The shortage of high-quality raw milk is the main factor determining the quality of production of all types of dairy products, since for milk-processing enterprises only milk produced in agricultural enterprises is practically accessible.

Fresh milk always contains a different number of mechanical impurities. Even with strict observance to sanitation and hygiene, it is possible to get animal wool, housing dust, epithelium, particles of mixed feed and litter, etc. into milk. In addition, the presence of all possible mechanical impurities in milk contributes to its high bacterial pollution [4-5]. 


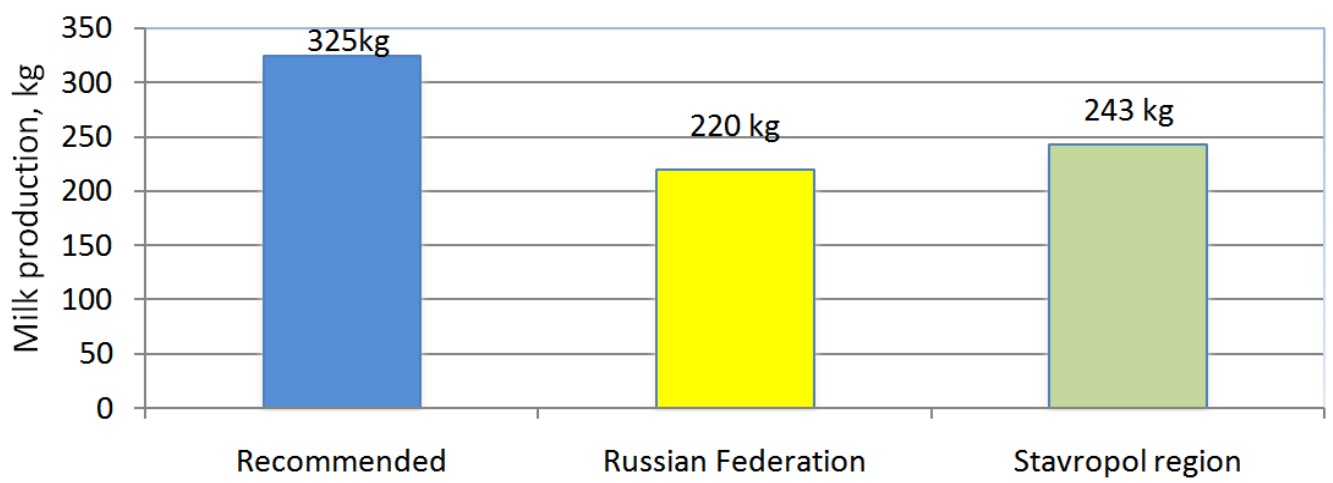

Fig. 3. Milk production per capita in 2017

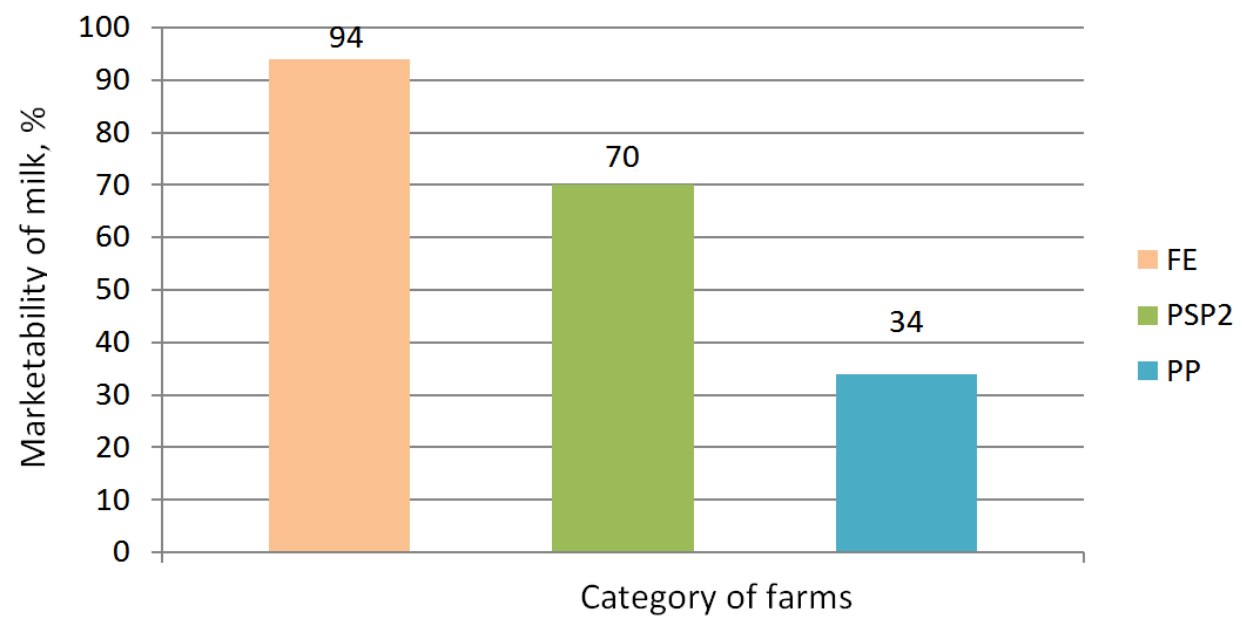

Fig. 4. Milk marketability produced by farms of different categories in 2017, \%

\section{Materials and methods}

In any manufacturing scheme of milk treatment and milk processing at the sites of its production, the initial and compulsory operation is clearing (Fig. 5). Therefore, the mechanical scavenging from milk is a fundamental factor in increasing its marketability. In accordance with the requirements of GOST R 52054-2003 "Natural cow milk - raw material" in force in the Russian Federation, three groups of purity are provided affecting the grade of milk quality. The first group of purity corresponds to milk of the first grade, the second group contains milk of the second grade, and milk having the third purity group belongs to the category of ungraded milk [6-7].

In spite of a wide variety of devices for mechanical milk clearing, filter materials and cartridges manufactured from them, they are all designed for limit load by contaminations. As a filter element becomes contaminated, the clearing efficiency is sharply reduced, being the main disadvantage of such devices. In this regard, the relevance of the problem under investigation is caused by the lack of homemade equipment that provides high performance milk clearing directly at the production sites, including farms and personal subsidiary plots.

At the Milking Units Laboratory of the Machinery and Technologies of Agro-industrial Complex Department at the Stavropol State Agrarian University, a filter design was developed providing a twostage cleaning of milk from contamination directly in the milking units. The general view and the filter scheme are shown in Fig. 6.

The filter operates under the pressure created by the milk pump. To increase the efficiency of milk clearing, the technological process is carried out consistently in two stages:

1. removal of large mechanical impurities (from $1.5 \mathrm{~mm}$ ) with tapping and collecting them in a settling tank;

2. removal of small impurities (from $40 \mathrm{mKm}$ ) with their stopping in the filter element. 


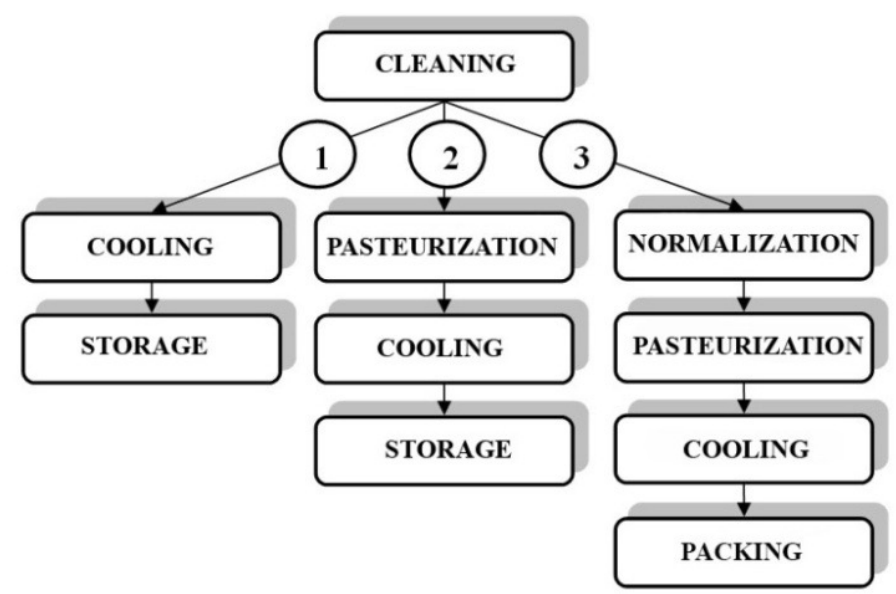

Fig. 5. Manufacturing schemes of primary milk processing and storage

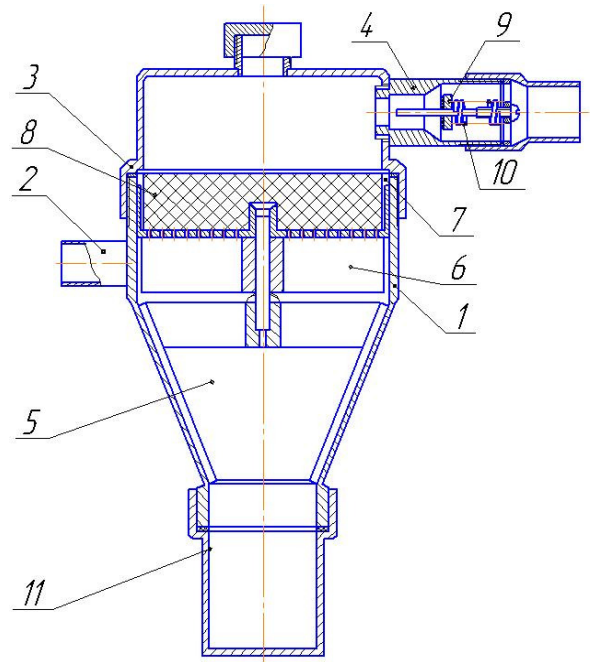

Fig. 6. Two-stage milk filter (patent No. 2115306): 1 - body; 2 - inlet pipe; 3 - cover; 4 - outlet pipe; 5 - diffuser; 6 -impeller; 7 - filter element housing; 8 - filtering element; 9 - piston; 10 - spring; 11 - settling tank

The filter consists of the body 1 with a tangentially located inlet pipe 2 , a cover 3 with an outlet pipe 4 . Inside the bogy there is a diffuser 5 , an impeller 6 , and a body 7 of the filtering element 8 . A piston 9 with a spring 10 is mounted in the outlet pipe. At the bottom of the body there is a settling tank 11.

When the milking unit is filled with milk, it is supplied to the pipe 2 by a pump, the tangential position of which ensures rotation of the impeller 6 closely fitting against the body surface 7 of the filter element having $1.5 \mathrm{~mm}$ holes. Large mechanical impurities retained by the body 7 are permanently removed from its surface by the rotating impeller 6 , then they are withdrawn to the periphery and through parallel-plate ducks between the filter body 1 and the diffuser 5 are sent to the settling tank 11 and remain in it (the 1st stage of clearing).

Pre-cleaned milk is pushed through the filter element 8 and finally the cleaned milk is get into the chamber of the cover 3, and then into the outlet pipe 4 (the 2nd stage of clearing). Increase of pressure inside the chamber of the cover 3 facilitates the opening of the piston 9, thus ensuring the free exit of milk from the filter.

By emptying a milk collector of the milking unit, the pump is disconnected, the pressure inside the cover 3 falls and the spring 10 returns the piston to its original position, ensuring milk to be pushed through the filter element in the opposite direction. This helps to clean the holes of the body filter element from the mechanical particles retained in them, and to drop them with help of the impeller, 
when the pump is reclosed in the settling tank. Then the cycle is repeated throughout the whole period of the milking machine operation.

The first stage of milk clearing from large mechanical impurities with a constant tap and collection in the settling tank, as well as periodic cleaning of the holes significantly reduce the load on the filter element of fine clearing, increasing the time of its continuous work. This contributes to the production of milk corresponding to the purity of its higher grades.

The main parameter of the filter element body is its throughput, which, in turn, is determined by the area and the number of holes.

The flow capacity of the filter should correspond to the maximum capacity of the milk pump. In addition, the allowable speed of the milk passage through the filter element should not exceed $0.6-0.8 \mathrm{~m} \cdot \mathrm{s}^{-1}$, as its excess leads to intensive erosion and destruction of delayed mechanical particles, as a result of which they become smaller (less than $40 \mu \mathrm{m}$ ) and are not retained by the filter element. Fig. 7 represents the body of the filter element, the parameters of which are determined for a filter with a throughput of $1500 \mathrm{l} / \mathrm{h}$ at a milk flow rate through a filter element of $0.6 \mathrm{~m} / \mathrm{s}$.
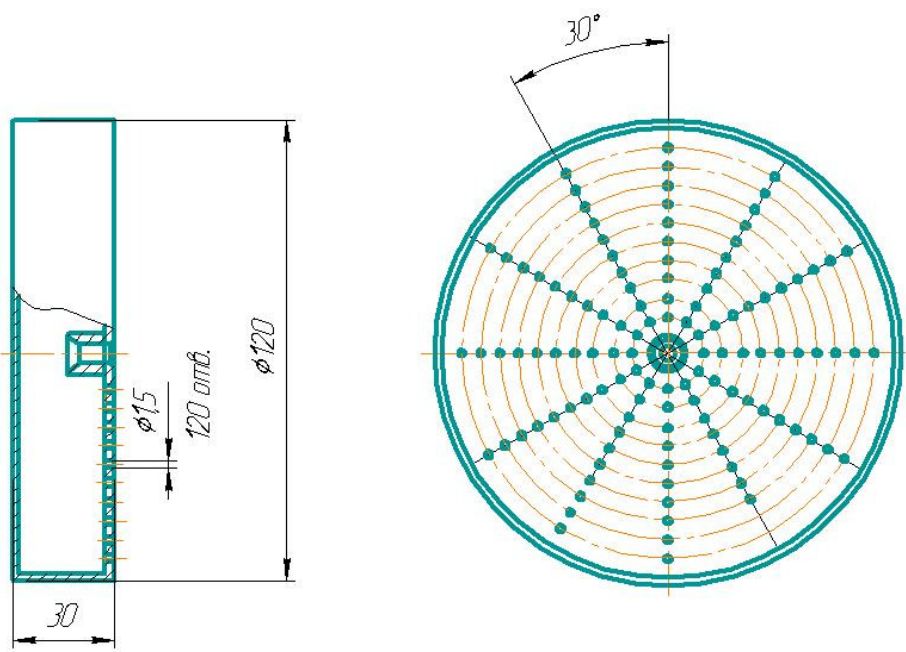

Fig. 7. Filter body

The filling time for the settling tank with large mechanical impurities depends on the amount of milk being treated and its initial contamination. Therefore, in order to use the filter in milking plants, as well as treatment and processing lines for milk collection stations and milk processing centers, it is equipped with different settling tanks $\left(50,75,100,125\right.$ and $\left.150 \mathrm{~cm}^{3}\right)$ [8-9].

\section{Results and discussion}

The working capacity of the developed filter was tested at the Milking Units Laboratory of the Machinery and Technologies of the Agro-industrial Complex Department at the Stavropol State University. The determination of milk mechanical contamination was carried out in accordance with GOST 8218-89. The method is based on determination of mechanical impurities by filtering $250 \mathrm{ml}$ of milk and comparison of the filter contamination with the standard. The milk of the third purity group was used as a raw product. Output volume was performed according to GOST 26809. As a result of research, the optimal thickness of the filter element (pos. 8, Fig. 6), which should range from 20 to $25 \mathrm{~mm}$ (Fig. 8), and the time of continuous work has been justified (Fig. 9).

The filter manufacturing test was carried out on the dairy farms of the SPK "Moskovskiy" of the Izobilnensky district, "Rodina" of the Blagodarny district, and the family dairy farm "I.A.Kasyanov" of the Novoselitsky district of the Stavropol Territory.

The data of manufacturing tests have confirmed that the efficiency of milk clearing from contamination reached 96-98\%, which corresponded to its highest grade. The completed technical and economic calculations showed that investment in filter development would pay within 1-1.5 years due to the most complete preservation of quality milk indicators. The basis for determining the economic efficiency of the filter is the difference in purchasing prices for milk depending on its grade. 


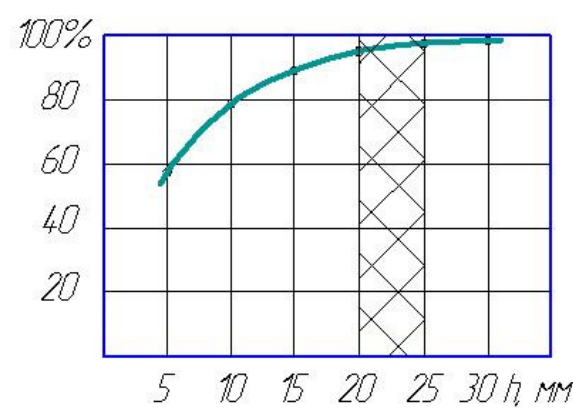

Fig. 8. Effect of thickness of filter element $h$ on efficiency of clearing milk

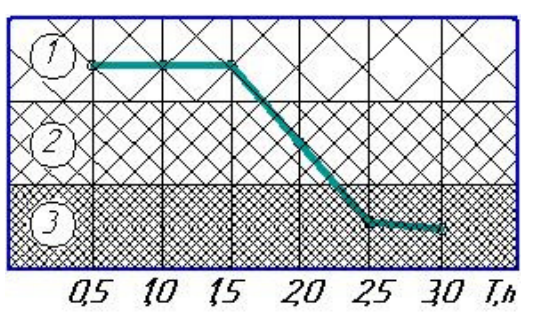

Fig. 9. Changing milk purity from time of continuous filter operation of $1,2,3$ - purity groups; $\mathbf{T}$ - time in hours

The results of the research were reported at the interuniversity scientific and international scientific conferences in 2016-2017. Also, the material presented was used in the preparation of the tutorial "Techniques and Technologies in Animal Husbandry", which was recommended by the Higher Educational Institution of the Russian Federation on Agro-engineering Education for students mastering the Bachelor and Master educational programs in the field of "Agro-engineering" training.

\section{Conclusions}

Today, in the Russian Federation, a half of the milk volume (of milk) produced falls on the share of LPH and KFH, which significantly reduces the marketability of the products. In this regard, highquality milk cleaning plays a crucial role in the profitability of its production.

The existing technical solutions for milk cleaning from mechanical impurities do not provide this product of the highest quality in accordance with the requirements of the current state Standard.

The proposed device, as shown by both laboratory and industrial tests, being subjected to the reasonable operating conditions, ensures the milk production of the highest quality due to its two-stage cleaning and forced removal of contaminants in the settling tank.

\section{References}

[1] Амерханов Х. А. Состояние и развитие молочного скотоводства в Российской Федерации (The status and development of dairy cattle breeding in the Russian Federation) / X.A. Амерханов // Journal dairy and beef cattle breeding. - 2017. - № 1. - pp. 2-5(In Russian).

[2] Chamberland, J.; Lessard, M.H.; Doyen, A. A sequencing approach targeting the 16S rRNA gene unravels the biofilm composition of spiral-wound membranes used in the dairy industry. Dairy science \& technology Vol: 6, 2017. pp. 827-843.

[3] Alessandro Bonanno, Carlo Russo and Luisa Menapace, Market power and bargaining in agrifood markets: A review of emerging topics and tools, Agribusiness, 34, 1, 2017, pp. 6-23.

[4] Kapustin I. V., Grinchenko V. A., Gritsai D. I., Kapustina E. I. The physiological requirements for the engineering of milking machines to reduce mastitis, Research Journal of Pharmaceutical, Biological and Chemical Sciences, (Vol.7), 2, 2016, pp. 338-343.

[5] Atanov I.V., Kapustin I.V., Grinchenko V.A., Gritsai D.I., Ka-pustina E.I. Improving efficiency of feeding cattle. Research Journal of Pharmaceutical, Biological and Chemical Sciences. 2016. T. 7. № 4. pp. 1927-1932.

[6] ГОСТ Р 52054-2003. Молоко натуральное коровье - сырье. Технические условия. Введен 2004-01-01. Изд. офиц. - Москва : Изд-во стандартов, 2003. - 6 с (In Russian).

[7] Nischkauer W, Vanhaecke F, Bernacchi S, Herwig C, Limbeck A (2014) Radial line-scans as representative sampling strategy in dried-droplet laser ablation of liquid samples deposited on precut flter paper disks. Spectrochim Acta B 101, pp. 123-129. doi:10.1016/j.sab.2014.07.023

[8] Пат. 2454859 Российская Федерация, МПК А01J11/06. Фильтр молочный двухступенчатый / И. В. Капустин, В. И. Будков, М. Ю. Братчиков; заявитель и патентообладатель ФГБОУ ВПО Ставропольский ГАУ. - № 2011111696/10 ; заявл. 28.03.2011 ; опубл. 10.07.2012, Бюл. № 19. 9 p.(In Russian).

[9] Молочный фильтр двухступенчатой очистки (Тwo-stage cleaning milk filter) / И. В. Капустин, Д. И. Грицай, В. И. Будков, Е. Г. Сидоров // Journal of rural mechanic. 2011. № 11. pp. 28-29 (In Russian). 